University of Nebraska - Lincoln

DigitalCommons@University of Nebraska - Lincoln

\title{
Microbial treatment of swine fecal waste to generate long-chain linear alkanes after fast pyrolysis
}

\author{
Lisa A. Fitzgerald \\ US Naval Research Laboratory, lisa.fitzgerald@nrl.navy.mil \\ C. Ziemer \\ USDA-ARS \\ S. E. Lizewski \\ US Naval Research Laboratory \\ Bradley R. Ringeisen \\ Naval Research Laboratory, Bradley.ringeisen@nrl.navy.mil \\ K. Henry \\ NMRC
}

See next page for additional authors

Follow this and additional works at: https://digitalcommons.unl.edu/usnavyresearch

Part of the Operations Research, Systems Engineering and Industrial Engineering Commons

Fitzgerald, Lisa A.; Ziemer, C.; Lizewski, S. E.; Ringeisen, Bradley R.; Henry, K.; and Biffinger, Justin C., "Microbial treatment of swine fecal waste to generate long-chain linear alkanes after fast pyrolysis" (2010). U.S. Navy Research. 20.

https://digitalcommons.unl.edu/usnavyresearch/20

This Article is brought to you for free and open access by the U.S. Department of Defense at DigitalCommons@University of Nebraska - Lincoln. It has been accepted for inclusion in U.S. Navy Research by an authorized administrator of DigitalCommons@University of Nebraska - Lincoln. 


\section{Authors}

Lisa A. Fitzgerald, C. Ziemer, S. E. Lizewski, Bradley R. Ringeisen, K. Henry, and Justin C. Biffinger 
conditioned. Analytical measurements (GC/MS, TGA/DSC,GC/FID) were performed on both bacterial fatty acid content and on the oils generated from the pyrolysis of the treated and un-treated waste. This presentation will describe a $>2 \%$ (per weight) increase in aviation fuel or lubricant products from the anaerobic treatment of swine waste with environmental microbes.

doi:10.1016/j.jbiotec.2010.08.392

[P-B.39]

Microbial treatment of swine fecal waste to generate long-chain linear alkanes after fast pyrolysis

L.A. Fitzgerald ${ }^{1, *}$, C. Ziemer $^{2}$, S.E. Lizewski ${ }^{1}$, B.R. Ringeisen ${ }^{1}$, K. Henry $^{3}$, J.C. Biffinger ${ }^{1}$

${ }^{1}$ US Naval Research Laboratory, United States

2 National Soil Tilth Lab, ARS-USDA, United States

${ }^{3}$ Biological Defense Research Directorate, NMRC, United States

Keywords: Biofuel; Waste remediation; Renewable aviation fuel; Pyrolysis

Research into the generation of energy from human and animal waste has been primarily focused on gas production (especially methane and hydrogen). While there is some work concentrated on ethanol and biodiesel creation from wastes (fuels used for ground transportation primarily), increasing research interest has been recently directed toward long chain hydrocarbon production for aviation fuels. Kerosene components from swine fecal waste have been generated from four natural sources: undigested dietary lipids, host lipids excreted in feces, bacterial cell walls and products of bacterial fermentation.

Both biological and thermochemical sections of this project will be discussed. We demonstrate the utility of using defined and conditioned microbial pre-treatments to selectively increase paraffin elements of JP-5 and aviation fuel lubricants within defined fecal waste streams. Environmental stressors ( $\mathrm{pH}$, nutrient, oxygen concentration) resulted in elevated concentrations of fatty acids with carbon chain length between $C_{8}$ and $C_{20}$ in the conditioned waste. Conditioned microbial consortia were sub-cultured into untreated waste to perpetuate the treatment cycle. We have established swine models and waste collection procedures in which marine microbes are currently being 